\title{
PENGARUH BUDAYA ORGANISASI DAN KOMPETENSI TERHADAP MOTIVASI KERJA PT. SELARAS MITRA SEJAHTERA
}

\section{Solehudin}

Prodi S1 Manajemen, Fakultas Ekonomi dan Bisnis, Universitas Singaperbangsa Karawang Jl. HS. Ronggowaluyo, Telukjambe Timur, Karawang, Jawa Barat, 41361

E-mail: solehudin@unsika.ac.id

\begin{abstract}
Abstrak
Penelitian ini bertujuan untuk mengetahui apakah Pengaruh Budaya Organisasi dan Kompetensi Terhadap Motivasi Kerja Karyawan PT Selaras Mitra Sejahtera secara parsial maupun simultan. Penelitian ini dilakukan dengan menggunakan metode deskriptif kuantitatif dan verifikatif, yaitu mengumpulkan, menyajikan, menganalisis, dan melakukan pengujian hipotesis, serta membuat kesimpulan dan saran. Sampel dikumpilkan dengan metode Sampling Jenuh dengan jumlah 140 responden dari populasi 140 karyawan. Teknik pengumpulandata menggunakan angket dan observasi. Untuk melihat pengaruh, analisis yang digunakan adalah path analisis. Sehingga dari hasil penelitian akan diketahui secara parsial variabel Budaya Organisasi dan Kompetensi mempunyaipengaruhyang signifikan terhadap Motivasi Kerja. Hasil Penelitian dapat disimpulkan bahwa terdapat Pengaruh Budaya Organisasi dan Kompetensi Terhadap Motivasi Kerja. Dan terdapat pengaruh simultan Budaya Organisasi $\left(X_{1}\right)$ dan Kompetensi $\left(X_{2}\right)$ Terhadap Motivasi Kerja (Y). Hal ini menunjukan bahwa motivasi dan disiplin kerja secara bersama-sama memiliki pengaruh terhadap kinerja karyawan PT. Putra Bintang Sembada.
\end{abstract}

Kata Kunci :Budaya Organsasi, Kompetensi, Motivasi Kerja

\begin{abstract}
This study aims to determine whether the Effect of Organizational Culture and Competence on Employee Work Motivation PT Selaras Mitra Sejahtera partially or simultaneously. This research was conducted using quantitative descriptive and verification methods, namely collecting, presenting, analyzing, and testing hypotheses, and making conclusions and suggestions. Samples were collected using Saturated Sampling method with 140 respondents from a population of 140 employees. Data collection techniques using questionnaires and observations. To see the effect, the analysis used is path analysis. So that the results of the study will be known partially variable Organizational Culture and Competence have a significant effect on Work Motivation. The research results can be concluded that there is an influence of organizational culture and competence on work motivation. And there is a simultaneous influence of Organizational Culture (X1) and Competence (X2) on Work Motivation (Y). This shows that motivation and work discipline together have an influence on the performance of employees of PT. Putra Bintang Sembada.
\end{abstract}

Keywords: Organizational Culture, Competence, Work Motivation 


\section{Pendahuluan}

Persaingan industri pada era globalisasi saat ini semakin tinggi dan semakin kompleks yang membawa dampak kepada perusahaan, sehingga setiap perusahaan di tuntut untuk memperbaiki hal-hal yang terkait dalam setiap perusahaan dan lebih responsive agar terus bertahan dan terus berkembang. Persaingan yang ketat pun terjadi pada industri semen di Indonesia. Industri semen memiliki peran yang besar dalam menopang pembangunan serta infrastruktur dan perekonomian di Indonesia. Hal ini menjadikan industri semen sebagai salah satu tulang punggung dalam kemajuan Negara Kesatuan Republik Indonesia.

Semen Merah Putih merupakan salah satu perusahaan industri semen yang berusaha bertahan dalam ketatnya persaingan. Sebagai market follower semen merah putih dituntut untuk terus menyesuaikan strateginya agar tetap bertahan dalam pasar. Dalam upaya merealisasikan strategi tersebut tentu perusahaan membutuhkan sumber daya manusia yang berkualitas sehingga mampu memberikan kontribusi yang tinggi bagi perusahaan.

Hal tersebut selaras dengan Edy Sutrisno(2009) sumber daya manusia merupakan suatu sumber daya yang sangat dibutuhkan oleh organisasi. Sebab, sumber daya manusia adalah sumber yang berperan aktif terhadap jalannya suatu organisasi. Sumber daya manusia di perusahaan perlu dikelola secara professional agar terwujud keseimbangan antara kebutuhan karyawan dengan tuntutan dan kemampuan organisasi perusahaan. Keseimbangan tersebut merupakan kunci utama perusahaan agar dapat berkembang secara produktif guna mencapai tujuan perusahaan.

Menurut Herzberg yang dikutip oleh Anoraga (2009) Husaini (2006) dalam Guntur Aryo Tejo dan Machasin (2015) dimana menurut para ahli bahwa kompetensi dan budaya organisasi merupakan beberapa faktor yang mempengaruhi motivasi kerja.

Tubagus Achmad Darodjat (2015:238) menegaskan bahwa budaya organiosasi merupakan hal dasar yang harus dimiliki sebuah perusahaan untuk dapat bertahan, terus maju dan berkembang, dan memenangkan persaingan dengan organisasi lain. 
Untuk mewujudkan tujuan tersebut para pendiri sebuah perusahaan harus mampu menbentuknya dan kemudian diwariskan kepada para karyawan sehingga seluruh insan yang terlibat dalam organisasi tersebut memiliki satu keyakinan dan pedoman yang sama dalam segala kegiatan mereka untuk mencapai kesukseskan.

pendapat Dharma dalam Edy Sutrisno (2009:209) bahwa kompetensi selalu mengandung maksud atau tujuan, yang merupakan dorongan motif atau trait yang menyebabkan suatu tindakan untuk memperoleh suatu hasil. Adapun Robbins dalam Edy Surtisno (2009:111), mengemukakan motivasi sebagai suatu kerelaan berusaha seoptimal mungkin dalam pencapaian tujuan organisasi yang dipengaruhi oleh kemampuan usaha memuaskan beberapa kebutuhan individu.

Dari berbagai masalah tersebut dapat diketahui bahwa jika perusahaan memiliki budaya organisasi yang baik dan kompetensi karyawan sesuai dengan kebutuhan perusahaan maka motivasi kerja karyawan akan meningkat. Hal ini akan memperkuat perusahaann untuk bertahan dan mampu berkembang dalam ketatnya persaingan global. Dengan dimilikinya motivasi maka karyawan akan memberikan kontribusi yang tinggi kepada perusahaan dan menyalurkan potensi-potensi yang dimilikinya dalam melakukan pekerjaan.

\section{Manajemen Sumber Daya Manusia}

Menurut Hasibuan (2016:1) Manajemen adalah ilmu dan seni mengatur proses pemanfaatan sumber daya manusia dan sumber - sumber lainnya secara efektif dan efisien untuk mencapai suatu tujuan.

Adapun pengertian Manajemen sumber daya manusia menurut T.Hani Handoko dalam Yulius Eka Agung Seputra mengemukakan bahwa Manajemen adalah proses perencanaan, pengorganisasian, pengarahan dan pengawasan usaha usaha para anggota organisasi dan penggunaan sumber daya - sumber daya organisasi lainnya agar mencapai tujuan organisasi yang telah ditetapkan.

Pengertian Manajemen sumber daya manusia Menurut G.R Terry dalam (Hasibuan, 2011:2) menyatakan bahwa Manajemen merupakan suatu proses khas yang terdiri atas tindakan-tindakan perencanaan, pengorganisasian, penggerakan, dan pengendalian untuk menentukan serta mencapai tujuan melalui pemanfaatan sumber daya manusia dan sumber daya alam. 


\section{Motivasi Kerja}

Menurut Edy Sutrisno (2016:146) Motivasi adalah suatu faktor yang mendorong seseorang untuk melakukan suatu aktifitas tertentu, oleh karena itu motivasi seringkali diartikan pula sebagai faktor pendorong perilaku seseorang.

David Mc.Clelland dalam Donni Juni Priansa (2016:208) mendefinisikan motivasi sebagai suatu kebutuhan yang bersifat sosial, kebutuhan yang muncul akibat perngaruh eksternal.

Hasibuan dalam Edi Sutrisno (2009:110) motivasi adalah pemberian daya penggerak yang menciptakan kegairahan kerja seseorang, agar mereka mau bekerjasama, bekerja efektif, dan terintegrasi dengan segala daya upayanya untuk mencapai kepuasan.

Dari pemaparan kajian teori mengenai motivasi kerja diatas maka dapat disimpulkan bahwa motivasi merupakan faktor yang dapat mendorong seseorang untuk melakukan suatu aktifitas dan mempengaruhi perlaku seseorang terhadap pekerjaannya dalam mencapai tujuan individual dan organisasi sebagai bentuk pemenuhan kebutuhan. serta didapatkan lima dimensi motivasi kerja yaitu kebutuhan fisiologis, kebutuhan rasa aman, kebutuhan sosial, kebutuhan pengakuan, dan kebutuhan aktualisasi diri.

\section{Budaya Organisasi}

Robbins dalam Masana Sembiring (2012:41) bahwa budaya organisasi mengacu ke sistem bersama yang dianut oleh anggota-anggota yang membedakan organisasi itu dari organisasi - organisasi lain.

Menurut Luthans (2007) dalam Syamsir Torang (2014:107) budaya organisasi adalah tata nilai dan norma yang menuntun perilaku jajaran organisasi .

Menurut Kreitner dan Kinicki dalam Syamsir Torang (2014:106) budaya organisasi adalah nilai dan keyakinan bersama yang mendasari identitas organisasi. Dari pemaparan kajian teori mengenai motivasi diatas maka dapat disimpulkan bahwa budaya organisasi adalah seperangkat sistem nilai - nilai dan keyakinan yang berlaku dalam sebuah organisasi yang diciptakan oleh pendiri organisasi lalu disosialisasikan kepada anggotanya dan diyakini oleh para anggotanya lalu dijadikan sebagai pedoman dalam melakukan pekerjaannya guna mencapai tujuan organisasi. 
Serta didapatkan enam dimensi budaya organisasi yaitu inovasi dan pengambilan resiko, perhatian ke hal yang rinci atau detail, orientasi hasil, orientasi orang, orientasi tim, dan keagresifan.

\section{Kompetensi}

Menurut Edy Sutrisno (2009:203) kompetensi adalah suatu kemampuan yang dilandasi oleh keterampilan dan pengetahuan yang didukung oleh sikap kerja serta penerapannya dalam melaksanakan tugas dan pekerjaan di tempat kerja yang mengacu pada persyaratan kerja yang ditetapkan.

Menurut Spencer dan Spencer dalam Edy Sutrisno (2009:202) mengatakan bahwa Kompetensi adalah suatu yang mendasari karakteristik dari suatu individu yang dihubungkan dengan hasil yang diperoleh dalam suatu pekerjaan. Karakteristik dasar kompetensi berarti kemampuan adalah sesuatu yang kronis dan dalam bagian dari kepribadian seseorang dan dapat diramalkan perilaku di dalam suatu tugas pekerjaan.

Menurut David Mc.Clelland yang dikutip oleh Sedarmayanti (2011:126) mengemukakan bahwa kompetensi adalah karakteristik mendasar yang dimiliki seseorang yang berpengaruh langsung terhadap kinerja yang sangat baik.

Dari paparan kajian teori mengenai kompetensi diatas maka dapat disimpulkan bawa kompetensi adalah suatu karakteristik seseorang yang merupakan perpaduan dari pengetahuan, keterampilan, nilai dan sikap yang menjadi kepribadian seseorang dalam menjalankan peran dan tanggung jawab dari pekerjaan yang diembannya. Serta didapatkan enam dimensi kompetensi yaitu pengetahuan, pemahaman, kemampuan, nilai, sikap dan minat.

\section{Hipotesis}

Berdasarkan rumusan masalah dan kerangka pemikiran dalam penelitian ini, maka rancangan hipotesis yang dihasilkan adalah :

H1 : Terdapat pengaruh budaya organisasiterhadap motivasi kerja di PT Selaras Mitra Sejahtera

H2 : Terdapat pengaruh kompetensi terhadap motivasi kerja di PT Selaras Mitra Sejahtera . 
H3 : Terdapat pengaruh budaya organisasi dan kompetensi secara bersama-sama terhadap motivasi kerja karyawan di PT Selaras Mitra Sejahtera.

\section{Metode Penelitian}

Metode penelitian pada dasarnya merupakan cara ilmiah untuk mendapatkan data dengan tujuan dan kegunaan tertentu. Cara ilmiah kegiatan penelitian itu didasarkan pada cirri-ciri keilmuan, yaitu rasional, empiris, dan sistematis (Sugiyono, 2015:2). Pada penelitian ini menggunakan metode penelitian deskriptif dan verifikatif.

\section{Variabel Penelitian dan Definisi Operasional Variabel}

\section{a. Variabel Penelitian}

Berdasarkan perumusan hipotesis diatas, maka variabel - variabel dalam penelitian ini adalah :

\section{Variabel Bebas (Independen)}

Variabel bebas atau independen merupakan variabel yang mempengaruhi atau menjadi sebab timbulnya atau berubahnya variabel dependen (variable terikat) (Sugiyono, 2002). Dalam penelitian ini yang merupakan variabel bebasnya adalah budaya organisasi (X1) dan kompetensi (X2).

\section{Variabel Terikat (Dependen)}

Variabel terikat atau dependen merupakan variabel yang dipengaruhi atau yang menjadi akibat karena adanya variabel bebas (independen). Dalam penelitian ini yang merupakan variabel terikatnya adalah motivasi kerja (Y) (Sugiyono, 2002).

\section{b. Definisi Operasional varibel}

\section{Budaya Organisasi (X1)}

\begin{tabular}{|c|l|l|}
\hline Variabel & \multicolumn{1}{|c|}{ Subvariabel } & \multicolumn{1}{|c|}{ Indikator } \\
\hline Budaya & 1. & Inovasi dan \\
Organisasi & pengambilan & Inovatif \\
\cline { 3 - 3 }$(\mathbf{X} 1)$ & resiko & Pengambilan resiko \\
\cline { 3 - 3 } & & Ketepatan \\
\hline
\end{tabular}




\begin{tabular}{|c|c|}
\hline \multirow{2}{*}{$\begin{array}{l}\text { 2. Perhatian ke hal } \\
\text { yang rinci atau } \\
\text { detail }\end{array}$} & Analisis \\
\hline & Perhatian yang detail \\
\hline 3. Orientasi hasil & Fokus hasil kerja \\
\hline 4. Orientasi orang & $\begin{array}{l}\text { Pertimbangan manajemen } \\
\text { terhadap anggota }\end{array}$ \\
\hline \multirow{2}{*}{ 5. Orientasi tim } & Menciptakan tim kerja \\
\hline & Mencapai tujuan bersama \\
\hline \multirow{2}{*}{ 6. Keagresifan } & Mampu Bersaing \\
\hline & Agresif dalam bersaing \\
\hline
\end{tabular}

\section{Kompetensi(X2)}

\begin{tabular}{|c|c|c|}
\hline \multirow{11}{*}{$\begin{array}{c}\text { Kompetensi } \\
\text { (X2) }\end{array}$} & \multirow{2}{*}{$\begin{array}{l}\text { 1. Pengetahuan } \\
\text { (knowledge) }\end{array}$} & Pengetahuan teknis kerja \\
\hline & & Pengetahuan prosedur kerja \\
\hline & \multirow[t]{2}{*}{$\begin{array}{l}\text { 2. Pemahaman } \\
\text { (understanding) }\end{array}$} & $\begin{array}{ll}\text { Pemahaman } & \text { tentang } \\
\text { karakteristik } & \end{array}$ \\
\hline & & $\begin{array}{l}\text { Kondisi kerja secara efektif dan } \\
\text { efisien }\end{array}$ \\
\hline & 3. Kemampuan (skill) & Kemampuan yang sesuai \\
\hline & \multirow{3}{*}{ 4. Nilai (Value) } & Kejujuran \\
\hline & & Demokratis \\
\hline & & Keterbukaan \\
\hline & \multirow{2}{*}{ 5. Sikap (attitude) } & Perilaku \\
\hline & & Penampilan \\
\hline & 6. Minat (interest) & Minat Bekerja \\
\hline
\end{tabular}

Motivasi Kerja (Y)

\begin{tabular}{|c|c|l|}
\hline \multirow{4}{*}{$\begin{array}{c}\text { Motivasi } \\
\text { (Y) }\end{array}$} & $\begin{array}{c}\text { 1. Kebutuhan } \\
\text { fisiologis }\end{array}$ & Upah yang sesuai \\
\cline { 3 - 3 } & $\begin{array}{l}\text { 2. } \\
\text { Kebutuhan rasa } \\
\text { aman }\end{array}$ & Istirahat/ Hari libur \\
\cline { 3 - 3 } & & Jeamanan kesehatan \\
\hline
\end{tabular}




\begin{tabular}{|c|c|}
\hline & Fasilitas kerja \\
\hline 3. Kebutuhan sosial & Kerjasama \\
\hline \multirow{2}{*}{$\begin{array}{l}\text { 4. Kebutuhan } \\
\text { penghargaan }\end{array}$} & Pengakuan \\
\hline & Penghargaan \\
\hline \multirow{3}{*}{$\begin{array}{l}\text { 5. Kebutuhan } \\
\text { aktualisasidiri }\end{array}$} & Keinginan berprestasi \\
\hline & Kebebasan berpendapat \\
\hline & $\begin{array}{l}\text { Keinginan mengembangkan } \\
\text { diri }\end{array}$ \\
\hline
\end{tabular}

\section{Populasi dan Sampel}

Dalam penelitian ini yang menjadi populasi adalah seluruh karyawan PT. Selaras Mitra Sejahtera yang berjumlah 140 orang. Berdasarkan populasi sebanyak 140 orang dan berdasarkan metode sampling jenuh dengan menggunakan seluruh populasi sebagai samper yaitu dengan sampel sebanyak 140 orang.

\section{Metode Pengumpulan Data}

Dalam penelitian ini, data yang digunakan adalah data primer, data ini dikumpulkan dengan cara menyebarkan kuesioner dengan scoring model likert. Data didapat dengan cara datang langsung ke PT. Selaras Mitra Sejahtera.

\section{Hasil Dan Pembahasan}

\section{a. Uji Validitas}

Motivasi kerja sebanyak 11 item kuisoner dinyatakan valid karena memiliki nilai $r$ hitung $>0.3$.

Kompetensi sebanyak 11 item kuisoner dinyatakan valid karena memiliki nilai $r$ hitung $>0.3$.

Budaya organisasi sebanyak 11 item kuisoner dinyatakan valid karena memiliki nilai $\mathrm{r}$ hitung $>0.3$. 
b. Uji Reliabilitas

\begin{tabular}{|l|l|l|l|}
\hline Variabel & R Hitung & R Kritis & Kriteria \\
\hline $\begin{array}{l}\text { Budaya Organisasi } \\
(\mathrm{X} 1)\end{array}$ & 0,808 & \multirow{2}{*}{0,60} & Reliabel \\
\cline { 1 - 2 } Kompetensi (X2) & 0,895 & & Reliabel \\
\cline { 1 - 2 } Motivasi Kerja (Y) & 0,806 & & Reliabel \\
\hline
\end{tabular}

Sumber : Hasil pengolahan data SPSS, 2017.

\section{c. Uji Normalitas}

\begin{tabular}{|l|l|l|l|}
\hline \multirow{2}{*}{ Variabel } & \multicolumn{2}{|l|}{ Kolomogrov Smirnov } & \multirow{2}{*}{ Kriteria } \\
\cline { 2 - 2 } & $\boldsymbol{\alpha}$ Hitung & $\boldsymbol{\alpha}$ Kritis & \\
\hline $\begin{array}{l}\text { Budaya Organisasi } \\
\left(\mathrm{X}_{1}\right)\end{array}$ & 3,914 & & $\begin{array}{l}\text { Distribusi } \\
\text { Normal }\end{array}$ \\
\cline { 1 - 2 } Kompetensi (X) & 3,394 & \multirow{2}{*}{0,05} & $\begin{array}{l}\text { Distribusi } \\
\text { Normal }\end{array}$ \\
& & & $\begin{array}{l}\text { Distribusi } \\
\text { Motivasi Kerja (Y) }\end{array}$ \\
& 2,894 & & Normal \\
\hline
\end{tabular}

Sumber : Hasil pengolahan data SPSS, 2017.

\section{Analisa Deskriptif}

\begin{tabular}{|l|l|l|l|}
\hline No . & Variabel & $\begin{array}{l}\text { Rata - } \\
\text { rata } \\
\text { Skor } \\
\text { Aktual }\end{array}$ & \\
& & Kriteria \\
\hline 1. & Budaya Organisasi (X1) & 469,1 & Cukup Setuju \\
\hline 2. & Kompetensi (X2) & 477,2 & Setuju \\
\hline 3. & Motivasi Kerja (Y) & 463 & Cukup Setuju \\
\hline
\end{tabular}

Sumber : Hasil pengolahan data SPSS, 2017 


\section{d. Analisis Verifikatif}

Korelasi Antara Budaya Organisasi ( $\left.\mathrm{X}_{1}\right)$ dan Kompetensi ( $\mathrm{X}_{2}$ )

\section{Correlations}

\begin{tabular}{|ll|l|l|}
\hline & & $\begin{array}{l}\text { Budaya_Or } \\
\text { ganisasi }\end{array}$ & $\begin{array}{l}\text { Kompeten } \\
\text { si }\end{array}$ \\
\hline $\begin{array}{l}\text { Budaya_Organis } \\
\text { asi }\end{array}$ & $\begin{array}{l}\text { Pearson } \\
\text { Correlation } \\
\end{array}$ & 1 &, $688^{* *}$ \\
& Sig. (2-tailed) & &, 000 \\
& N & 140 & 140 \\
\hline Kompetensi & Pearson &, $688^{* *}$ & 1 \\
& Correlation & & \\
& Sig. (2-tailed) &, 000 & 140 \\
\hline & N & 140 & \\
\hline
\end{tabular}

**. Correlation is significant at the 0.01 level (2-tailed).

\section{e. Analisis Jalur (Path Analysis )}

Berdasarkan hasil pengolahan data, diperoleh koefisien jalur untuk setiap variabel Budaya Organisasi $\left(\mathrm{X}_{1}\right)$ dan Kompetensi $\left(\mathrm{X}_{2}\right)$ terhadap Motivasi Kerja $(\mathrm{Y})$. Hasil analisis tersebut seperti di bawah ini :

\section{Coefficients ${ }^{\mathrm{a}}$}

\begin{tabular}{|c|c|c|c|c|c|c|}
\hline \multirow{2}{*}{\multicolumn{2}{|c|}{ Model }} & \multicolumn{2}{|c|}{$\begin{array}{l}\text { Unstandardized } \\
\text { Coefficients }\end{array}$} & \multirow{2}{*}{$\begin{array}{l}\text { Standardiz } \\
\text { ed } \\
\text { Coefficients } \\
\text { Beta }\end{array}$} & \multirow[b]{2}{*}{$\mathrm{t}$} & \multirow[b]{2}{*}{ Sig. } \\
\hline & & B & Std. Error & & & \\
\hline & $\begin{array}{l}\text { (Constant) } \\
\text { budaya_organi } \\
\text { sasi }\end{array}$ & $\begin{array}{l}-, 994 \\
, 544\end{array}$ & $\begin{array}{l}1,063 \\
, 035\end{array}$ & ,539 & $\begin{array}{l}-, 935 \\
15,638\end{array}$ & $\begin{array}{l}, 352 \\
, 000\end{array}$ \\
\hline & Kompetensi &, 415 & ,029 & ,502 & 14,546 & ,000 \\
\hline
\end{tabular}

a. Dependent Variable: Motivasi 


\section{f. Uji Hipotesis}

\section{Korelasi antara Motivasi $\left(\mathrm{X}_{1}\right)$ dan Disiplin Kerja $\left(\mathrm{X}_{2}\right)$}

$$
t=\frac{r \sqrt{n-2}}{\sqrt{1-r^{2}}}
$$

Diketahui :

$$
\begin{aligned}
& r=0,688 \\
& n=140
\end{aligned}
$$

Maka:

$$
\begin{gathered}
t=\frac{0,688 \sqrt{140-2}}{\sqrt{1-0,688^{2}}} \\
t=\frac{0,688(11,75)}{0,73} \\
t=\frac{8,084}{0,73} \\
t=11,073
\end{gathered}
$$

Nilai thitung di atas selanjutnya dibandingkan dengan tabel, pada tingkat kesalahan $5 \%, \mathrm{db}=\mathrm{n}-2=140-2=138$, maka diperoleh tabel $=1,655$. Dengan demikian diketahui thitung $(11,073)>$ tabel $(1,655)$, maka dapat dinyatakan bahwa Ho ditolak, artinya ada hubungan yang signifikan antara Budaya Organisasi ( $\mathrm{X}_{1}$ ) dan Kompetensi ( $\left.\mathrm{X}_{2}\right)$.

\section{Pengaruh Parsial}

Budaya Organisasi ( $\mathrm{X}_{1}$ ) Terhadap Motivasi Kerja ( $\mathrm{Y}$ )

\begin{tabular}{|l|l|l|l|l|l|}
\hline Struktural & Sig. & $\mathbf{A}$ & $\mathbf{t}_{\text {hitung }}$ & $\mathbf{t}_{\text {tabel }}$ & Kesimpulan \\
\hline $\operatorname{\rho yx}_{1}$ & 0,000 & 0,05 & 15,638 & 1,655 & $\mathrm{H}_{0}$ ditolak \\
\hline
\end{tabular}

Sumber : Hasil Pengolahan Data, 2017 
Kompetensi ( $\left.\mathrm{X}_{2}\right)$ Terhadap Motivasi Kerja (Y)

\begin{tabular}{|l|l|l|l|l|l|}
\hline Struktural & Sig. & A & thitung & ttabel & Kesimpulan \\
\hline pyx 2 & 0,000 & 0,05 & 14,546 & 1,655 & $\mathrm{H}_{0}$ ditolak \\
\hline
\end{tabular}

Sumber : Hasil Pengolahan Data, 2017

\section{Pengaruh Variabel secara Simultan}

\section{Hasil Perhitungan F}

ANOVA $^{\mathrm{a}}$

\begin{tabular}{|ll|l|l|l|l|l|}
\hline \multicolumn{2}{|l|}{ Model } & $\begin{array}{l}\text { Sum } \\
\text { Squares }\end{array}$ & Df & $\begin{array}{l}\text { Sean } \\
\text { Square }\end{array}$ & F & Sig. \\
\hline 1 & $\begin{array}{l}\text { Regressi } \\
\text { on }\end{array}$ & 4388,739 & 2 & 2194,369 & 729,70 &, $000^{\mathrm{b}}$ \\
& $\begin{array}{l}\text { Residual } \\
\text { Total }\end{array}$ & 411,985 & 137 & 3,007 & & \\
& 4800,724 & 139 & & & \\
\hline
\end{tabular}

a. Dependent Variable: Motivasi

b. Predictors: (Constant), Kompetensi, budaya_organisasi

Sumber : Hasil Pengolahan data, 2017

\section{Pengaruh Simultan Budaya Organisasi $\left(X_{1}\right)$ dan Kompetensi $\left(X_{2}\right)$}

\section{Terhadap Motivasi Kerja ( Y)}

\begin{tabular}{|l|l|l|l|l|l|}
\hline Struktural & Sig. & A & fhitung & ftabel & Kesimpulan \\
\hline Pyx1X2 & 0,000 & 0,05 & 729,708 & 2,28 & Ho ditolak \\
\hline
\end{tabular}

Sumber : Hasil Pengolahan Data, 2017

\section{Pembahasan}

\section{Pembahasan Deskriptif}

Adapun pembahasan dari metode deskriptif mengenai masing - masing variabel dalam penelitian ini dapat diuraikan sebagai berikut.

1. Berdasarkan hasil penelitian menunjukan bahwa Budaya Organisasi berdasarkan hasil kuesioner diperoleh nilai dengan rata-rata skor sebesar 469,1 yang berada pada rentang skala 364 - 476 dengan kriteria Cukup Setuju. Terdapat 
indikator yang memiliki nilai terendah yaitu inovasi dan agresif dalam bersaing. Artinya pihak perusahaan harus mendorong karyawan agar dapat melakukan pekerjaan dengan cara baru yang lebih inovatif agar tidak menimbulkan kejenuhan saat bekerja dan memberikan apresiasi kepada karyawan yang mampu bekerja dengan semangat tinggi atau berprestasi dalam bekerja agar karyawan mampu bersaing untuk mendapatkan hasil kerja yang terbaik.

2. Berdasarkan hasil penelitian menunjukan bahwa Kompetensi pada karyawan PT Selaras Mitra Sejahtera berdasarkan hasil kuesioner diperoleh nilai dengan rata-rata skor sebesar 477,2 yang berada pada rentang skala 476 - 588 dengan kriteria Setuju. Terdapat indikator yang memiliki nilai terendah yaitu pengetahuan teknis kerja dan pengetahuan tentang prosedur kerja, artinya pihak perusahaan harus dapat mensosialisasikan kembali tentang teknis dan prosedur kerja dan meberikan pelatihan kepada karyawan agar dapat menguasai teknis dan prosedur kerja dengan baik.

3. Berdasarkan hasil penelitian menunjukan bahwa Motivasi kerja pada Karyawan PT Selaras Mitra Sejahtera berdasarkan hasil kuesioner diperoleh nilai dengan rata - rata skor sebesar 463 yang berada pada rentang skala 364 - 463 dengan kriteria Cukup Setuju. Terdapat indikator yang memiliki nilai terendah yaitu upah yang sesuai dan keinginan untuk mengembangkan diri, artinya pihak perusahaan harus memperbaiki sistem upah agar sesuai dengan pekerjaan yang diemban oleh karyawan dan memberikan kesempatan kepada karyawan untuk mengembangkan kemampuan yang dimiliki dalam pekerjaan.

\section{Pembahasan Verifikatif}

Adapun pembahasan dari metode Verifikatif dalam penelitian ini dapat diuraikan sebagai berikut.

1. Hubungan antara Budaya Organisasi (X1) dengan Kompetensi (X2) memiliki nilai koefisien korelasi sebesar 0,688 dan mempunyai hubungan yang kuat dan searah karena nilainya positif.

2. Pengaruh parsial Budaya Organisasi (X1) dan Kompetensi (X2) Terhadap Motivasi Kerja (Y). 
a. Pengaruh Parsial Budaya Organisasi (X1) terhadap Motivasi Kerja (Y) adalah sebesar 0,539, dengan nilai sig. $(0,000)<\alpha(0,05)$ dan thitung $(15,638)>$ ttabel (1,655), maka H0 ditolak. Dan kontribusi dari variabel Budaya Organisasi (X1) terhadap Motivasi Kerja (Y) yaitu sebesar 0,477 atau 47,7\%. Hal ini menunjukkan bahwa Budaya Organisasi (X1) memiliki Kontribusi positif terhadap Motivasi Kerja (Y).

b. Pengaruh Parsial Kompetensi (X2) terhadap Motivasi Kerja (Y) adalah sebesar 0,502, dengan nilai sig. $(0,000)<\alpha(0,05)$ dan thitung $(14,546)>$ ttabel $(1,655)$, maka H0 ditolak. Dan Kontribusi variabel Kompetensi (X2) terhadap Motivasi Kerja (Y) yaitu sebesar 0,438 atau 43,8\%. Hal ini menunjukkan bahwa Kompetensi (X2) memiliki kontribusi yang positif terhadap Motivasi Kerja (Y).

3. Budaya Organisasi $\left(\mathrm{X}_{1}\right)$ dan Kompetensi $\left(\mathrm{X}_{2}\right)$ Terhadap Motivasi Kerja (Y) dengan kriteria nilai uji nilai sig. $(0,000)<\alpha(0,05)$ dan fhitung $(729,708)>$ $\mathrm{f}_{\text {tabel }}(2,28)$, maka $\mathrm{H}_{0}$ ditolak. Total Pengauh Budaya Organisasi $\left(\mathrm{X}_{1}\right)$ dan Kompetensi ( $\left.\mathrm{X}_{2}\right)$ memiliki kontribusi terhadap Motivasi Kerja (Y) sebesar 91,4\% sedangkan sisanya 8,6\% merupakan kontribusi variabel lain $(\varepsilon)$ yang tidak diteliti.

\section{Simpulan}

1. Budaya Organisasiberdasarkan hasil kuesioner diperoleh nilai dengan rata - rata skor sebesar 469,1 yang berada pada rentang skala 364 - 476 dengan kriteria Cukup Setuju. Terdapat indikator yang memiliki nilai terendah yaitu inovasi dan agresif dalam bersaing. Artinya pihak perusahaan harus mendorong karyawan agar dapat melakukan pekerjaan dengan cara baru yang lebih inovatif dan mampu bersaing untuk mendapatkan hasil kerja yang lebih baik.

2. Kompetensi pada karyawan PT Selaras Mitra Sejahteraberdasarkan hasil kuesioner diperoleh nilai dengan rata - rata skor sebesar 477,2 yang berada pada rentang skala 476 - 588 dengan kriteria Setuju. Terdapat indikator yang memiliki nilai terendah yaitu pengetahuan teknis kerja dan pengetahuan tentang prosedur kerja, artinya pihak perusahaan harus dapat mensosialisasikan kembali 
tentang teknis dan prosedur kerja dan meberikan pelatihan kepada karyawan agar dapat menguasai teknis dan prosedur kerja dengan baik.

3. Motivasi kerja pada Karyawan PT Selaras Mitra Sejahteraberdasarkan hasil kuesioner diperoleh nilai dengan rata - rata skor sebesar 463 yang berada pada rentang skala 364 - 463 dengan kriteria Cukup Setuju. Terdapat indikator yang memiliki nilai terendah yaitu upah yang sesuai dan keinginan untuk mengembangkan diri, artinya pihak perusahaan harus memperbaiki sistem upah agar sesuai dengan pekerjaan yang diemban oleh karyawan dan memberikan kesempatan kepada karyawan untuk mengembangkan kemampuan yang dimiliki dalam pekerjaan.

4. Hubungan antara Budaya Organisasi $\left(\mathrm{X}_{1}\right)$ dengan Kompetensi $\left(\mathrm{X}_{2}\right)$ memiliki nilai koefisien korelasi sebesar 0,688, hal ini menunjukan terdapat hubungan yang kuat dan searah antara budaya organisasi dan kompetensi karena nilai korelasinya positif.

5. Pengaruh parsial Budaya Organisasi $\left(\mathrm{X}_{1}\right)$ dan Kompetensi $\left(\mathrm{X}_{2}\right)$ Terhadap Motivasi Kerja (Y).

a. Pengaruh Budaya Organisasi ( $\mathrm{X}_{1}$ ) terhadap Motivasi Kerja (Y) sebesar 0,539 Hal ini menunjukkan bahwa Budaya Organisasi (X1) memiliki Kontribusi positif terhadap Motivasi Kerja (Y).

b. Pengaruh Kompetensi ( $\mathrm{X}_{2}$ ) terhadap Motivasi Kerja (Y) sebesar 0,502. Hal ini menunjukkan bahwa Kompetensi $\left(\mathrm{X}_{2}\right)$ memiliki kontribusi yang positif terhadap Motivasi Kerja (Y).

6. Budaya Organisasi $\left(\mathrm{X}_{1}\right)$ dan Kompetensi $\left(\mathrm{X}_{2}\right)$ berpengaruh terhadap Motivasi Kerja (Y) dengan kriteria nilai uji nilai sig. $(0,000)<\alpha \quad(0,05)$ dan fhitung $(729,708)>f_{\text {tabel }}(2,28)$, maka $\mathrm{H}_{0}$ ditolak. Total Pengaruh Budaya Organisasi $\left(\mathrm{X}_{1}\right)$ dan Kompetensi $\left(\mathrm{X}_{2}\right)$ memiliki kontribusi terhadap Motivasi $(\mathrm{Y})$ sebesar 91,4 \% sedangkan sisanya 8,6\% merupakan kontribusi variabel lain $(\varepsilon)$ yang tidak diteliti. 


\section{Daftar Pustaka}

Donni, J. P. (2016). Perencanaan \& Pengembangan SDM. Bandung : Alfabeta.

Fahmi Irham. (2014). Perilaku Organisasi.Bandung : Alfabeta.

Hasibuan. (2011). Manajemen Dasar, Pengertian, dan Masalah. Jakarta : Bumi Aksara.

Riduwan. (2010). Dasar-dasar Statistika. Bandung: Alfabeta.

Sedarmayanti. (2011). Tata Kerja dan Produktivitas keraj. Bandung : CV Mandar Maju

Sembiring Masana. (2012). Budaya dan Kinerja Organisasi: Perspektif Organisasi Pemerinta. Fokus Media : Bandung.

Sugiyono. (2016). Metode Penelitian Manajemen. Bandung: Alfabeta.

Sugiyono.(2015). Metode Penelitian Manajemen.Bandung : Alfabeta.

Sutrisno, E. (2016). Manajemen Sumber Daya Manusia. Jakarta : Kencana.

S.P.Hasibuan, M. (2016). Manajemen Sumber Daya Manusia. Jakarta : Bumi Aksara.

Torang Syamsir. (2014) Organisasi \& Manajemen (PERILAKU, STRUKTUR, BUDAYA \& PERUBAHAN ORGANISASI).Bandung : Alfabeta.

Wibowo.(2016). Manajemen Kinerja.Jakarta : Rajawali Pers.

Yulius, E. A. S. (2014). Manajemen dan Perilaku Organisasi. Yogyakarta : Graha Ilmu.

Guntur Aryo Tejo dan Machasin. 2015. Universitas Riau. Pengaruh Kompetensi dan Budaya Organisasi Terhadap Motivasi Kerja Serta Dampaknya Terhadap Kinerja Personil Bid. Humas Polda Riau

Nur Octavian. 2011. Fakultas Ekonomi Universitas Pembangunan Nasional "Veteran" Yogyakarta.Pengaruh Budaya Organisasi Terhadap Motivasi dan Kepuasan Kerja Serta Kinerja Karyawan Pada PT. Mirota Kampus Di Yogyakarta.

Mauledy Ahmad dan Marwan. 2013. Yogyakarta. Pengaruh Kompetensi, Kompensasi dan Lingkungan Kerja Terhadap Motivasi Kerja Pada Pegawai Kantor Camat di Kota Sungai Penuh

Indra Rizky Oktavian.2011. Fakultas Ekonomi Universitas Negeri Semarang. Pengaruh Motivasi Kerja Dan Budaya Organisasi Terhadap Kinerja Karyawan Di Lingkungan $\mathrm{Pt}$.

http://megapolitan.kompas.com/read/2017/01/09/191500126/konsumsi.semen.di.20 17.diprediksi.naik.jadi.84.96.juta.ton

http://economy.okezone.com/read/2014/05/13/279/984121/kontribusi-industrisemen-bagi-pembangun 